\title{
LIVER TRAUMA WITH ASSOCIATED EXTERNAL INJURIES AND OTHER INTERNAL VITAL ORGAN INJURIES - AN AUTOPSY BASED STUDY
}

\author{
C. S. Sreedevi ${ }^{1}$, Sreelekshmi $J^{2}$ \\ 1 Professor and HOD, Department of Forensic Medicine and Toxicology, Government T. D. Medical College, Alappuzha. \\ 2Junior Resident, Department of Forensic Medicine and Toxicology, Government T. D. Medical College, Alappuzha.
}

\begin{tabular}{l} 
ABSTRACT \\
\hline BACKGROUND \\
Liver injury is one of the most common causes of death in blunt trauma in the abdomen. The large size, approximately central location \\
and relative friability of the organ combine to render it vulnerable to injury by mechanical violence applied either to abdom en or \\
thorax. Very often forensic pathologists are required to give an opinion as to the nature and degree of trauma from which the injury \\
could have resulted. In the presence of right-sided haemothorax and right-sided rib fracture in various traumatic occurrences (like \\
fall from height, kicks, occupants of vehicle, etc.) a suspicion about hepatic injury can help in timely intervention.
\end{tabular}

\section{MATERIALS AND METHODS}

A cross-sectional study was conducted at Government Medical College, Trivandrum based on medicolegal autopsies done for a period of one year. All autopsies in which the alleged cause of death was trauma were closely observed and in those cases where liver injury was found were selected for the study. A total of 88 cases were studied and information regarding the clinical details, cause of trauma and the period of survival were obtained. Liver was examined in situ and detailed examination was done after evisceration.

\section{RESULTS}

In the 88 cases of liver trauma examined $86(97.7 \%)$ were due to non-penetrating liver injuries. Majority of the cases were due to road traffic accidents 59 (67\%). Majority of the deaths, 62 (70.4\%), occurred within an hour. Only $6(6.8 \%)$ cases survived more than one day. Twenty one (23.9\%) cases have received treatment. In $18(85.71 \%)$ treated cases, liver injury was not suspected or detected clinically. In $44(50 \%)$ cases of liver injury, external injury on the abdomen was absent. The most common external injury on the abdomen was abrasions, 28 (63.6\%). Right side of front of abdomen and middle of front of abdomen were the usual sites of impact, $15(34.1 \%)$. Fractured ends of ribs were responsible for associated injury to right lobe of liver. Spleen was the organ frequently affected (32.3\%) along with hepatic injury.

\section{CONCLUSION}

The most common cause of liver injury was road traffic accidents followed by railway occurrences. Liver can be injured without any injury to the abdominal wall as seen in $50 \%$ cases. The role of liver injury contributing to death when associated with injuries to other vital organs could not be discerned in all cases. Incidence of right-sided rib fracture was an associated feature in $57.9 \%$ cases.

\section{KEYWORDS}

Liver Injury, Trauma, Death.

HOW TO CITE THIS ARTICLE: Sreedevi CS, Sreelekshmi J.Liver trauma with associated external injuries and other internal vital organ injuries - An autopsy based study. J. Evolution Med. Dent. Sci. 2016;5(98):7196-7199, DOI: 10.14260/Jemds/2016/1628

\section{BACKGROUND}

Liver is the largest gland present in the human body and its injury is one of the most common cause of death following blunt trauma in the abdomen.1,2 The large size, approximately central location and relative friability of the organ combine to render it vulnerable to injury by mechanical violence applied either to abdomen or the thorax. ${ }^{3}$ In the case of lower right thoracic injury, liver is often the only organ damaged. Liver lacerations can occur in association with other injuries such as rib fractures, ruptures of diaphragm and pulmonary contusions. Very often forensic pathologists are required to

Financial or Other, Competing Interest: None.

Submission 03-11-2016, Peer Review 27-11-2016,

Acceptance 03-12-2016, Published 08-12-2016.

Corresponding Author:

Dr. Sreelekshmi J,

Junior Resident,

Department of Forensic Medicine and Toxicology,

T. D. Medical College,

Alappuzha.

E-mail:jsreelekshmij@gmail.com

DOI: $10.14260 /$ jemds $/ 2016 / 1628$

\section{(c) $(i) \Theta$}

give an opinion as to the nature and degree of trauma from which the injury could have resulted. Liver injuries are broadly classified into penetrating and non-penetrating injuries. The most common cause of non-penetrating injury of liver is automobile accidents followed by kicks, blows or falling; mostly by forces of compression. ${ }^{4}$ Penetrating wounds of the lower chest often extend through the diaphragm and injure the liver. In extensive hepatic injury, pain and rapid blood loss will almost invariably dominate. A suspicion about hepatic injury in the presence of right-sided haemothorax or fractured ribs, a fractured pelvis, after fall from heights or an injury of the spinal column in patients who were wearing a seat belt at the time of injury, can help in timely intervention.

\section{Aims and Objectives}

1. To study the relation of traumatic liver injury to external bodily injuries.

2. To study the occurrence of associated internal injuries to other vital organs along with liver trauma.

3. To assess the period of survival among the traumatic liver injury victim. 


\section{MATERIALS AND METHODS}

A cross-sectional study at Government Medical College Trivandrum, based on medicolegal autopsies, was done over a period of one year, to find out the relation between traumatic liver injuries with external injuries and internal vital organ injuries. All autopsies in which the alleged cause of death was trauma were closely observed, and in those cases where liver injury was found were selected for the study. A total of 88 cases were studied in detail. The types of cases that came under the purview included: 1. Road traffic accidents. 2 . Railway occurrences. 3. Fall from height. 4. Fall of heavy objects on the body. 5. Birth trauma in newborns. 6 . Assaults with a) blunt objects b) sharp objects. 7. Injuries by animals. 8 . Other relevant cases.

\section{Data Collection}

Information regarding the cause of trauma and the period of survival were obtained from the requisition for post-mortem examination. Clinical details, period of survival, etc were gathered from relevant clinical case records of hospitals in which the patient was treated. Liver was examined in situ to avoid artefacts. Detailed examination was done after evisceration. All the details were recorded in the proforma. Photographs were taken in sample cases.

Data was entered into MS excel for data analysis. Qualitative variables are represented using frequency and proportions. Privacy and confidentiality of the data was maintained during the study.

\section{RESULTS}

A total of 88 study cases of liver trauma brought for medicolegal autopsy were examined. Among the study cases, $77(87.5 \%)$ were male and $11(12.5 \%)$ were female and maximum cases of liver injury $55(62.5 \%)$ were between the age of 21 to 50 years (Table 1). Non-penetrating liver injuries constituted $97.7 \%(n=86)$ of cases. Out of this, 59 (67\%) were due to road traffic accidents. Railway occurrences were responsible for $11(12.5 \%)$ cases and 7 (7.9\%) were due to fall from heights. Three cases each $(3.4 \%)$ of liver injuries were due to fall of heavy objects on the body and assault. In the traffic accidents, 43 (48.9\%) were occupants of various types

\begin{tabular}{|c|c|c|c|}
\hline Age (Years) & $\begin{array}{c}\text { Male } \\
\text { N (\%) }\end{array}$ & $\begin{array}{c}\text { Female } \\
\text { N (\%) }\end{array}$ & $\begin{array}{c}\text { Total } \\
\text { N (\%) }\end{array}$ \\
\hline $0-10$ & $3(3.9)$ & $2(18.2)$ & $5(5.6)$ \\
\hline $11-20$ & $5(6.5)$ & $3(27.3)$ & $8(9.1)$ \\
\hline $21-30$ & $18(23.4)$ & $0(00)$ & $18(20.4)$ \\
\hline $31-40$ & $16(20.8)$ & $4(36.4)$ & $20(22.7)$ \\
\hline $41-50$ & $16(20.8)$ & $1(9.1)$ & $17(19.3)$ \\
\hline $51-60$ & $10(13)$ & $0(00)$ & $10(11.4)$ \\
\hline Above 60 & $9(11.7)$ & $1(9.1)$ & $10(11.4)$ \\
\hline \multicolumn{6}{|c|}{ Total (100) } & $11(100)$ & $\mathbf{8 8}(100)$ \\
\hline Table 1. Age and Sex Distribution of the Study Subjects \\
(Traumatic Liver Injury Victims) \\
\hline \multicolumn{4}{|c}{}
\end{tabular}

of vehicles and 16 (18.2\%) were pedestrians (Fig 1). Heavy vehicles and four wheelers were responsible for 30 (50.84\%) of liver injury cases. Three wheelers caused liver injury in 11 cases $(18.6 \%)$ and two wheelers in $18(30.5 \%)$. Penetrating injuries were seen in $2(2.3 \%)$ cases and were caused by stabbing with knives.

In $44(50 \%)$ cases, external injury to the abdomen was absent (Table 2). No injury was seen on the trunk in 15 (17\%) cases, but in $8(9 \%)$ cases external injury was seen on the right upper limb. The most common external injury on the abdomen was abrasions, in 28 (31.8\%) cases, followed by contusions in $14(15.9 \%)$ cases and lacerations in $9(10.2 \%)$ (Table 3$)$. Among 44 (50\%) cases, right side of front of abdomen in and middle of front of abdomen were the usual sites of impact, as observed in 15 (34.1\%) cases. Injury on the left side of abdomen and left side of back of abdomen caused liver injuries were seen in $4(9.1 \%)$ and $6(13.6 \%)$ cases respectively.

In 29 cases $(32.9 \%)$, there were no external injuries to abdomen, but there were external injuries to chest (Table 4). Associated fatal injuries were found in the chest in 63 (71.6\%) cases. Right-sided rib fractures were found in 51 (57.9\%) cases (Table 5). Among the chest injuries, lungs were affected in $15(23.8 \%)$ cases and sternal fracture in $5(7.9 \%)$ cases. Oesophagus and heart were least affected $1(1.6 \%)$ case each, fractured ends of ribs were responsible for most of the lung lacerations and associated injury to right lobe of liver. Fatal brain injury was seen in 58 (65.9\%) cases. Associated fatal injury to other abdominal organ was observed in 31 (35.2\%) cases. Among the other abdominal organs, spleen was frequently affected, as observed in 10 (32.3\%) cases (Fig 2).

Fracture of vertebral column was observed in $14(15.9 \%)$ cases. Most of these were in railway occurrences $(n=6)$ and road traffic accidents occupants $(n=5)$. Only 2 cases of road traffic accident pedestrians and 1 case of fall from height had vertebral fracture. Out of 88 cases, death occurred on the spot in $29(32.9 \%)$ cases. Only $6(6.8 \%)$ victims survived more than one day (Table 6).

Twenty one $(23.9 \%)$ cases received treatment. Among them, the majority that is $18(85.7 \%)$ treated cases, liver injury was not suspected or detected clinically. Laparotomy was done in 2 cases.

\begin{tabular}{|c|c|c|}
\hline \multirow[b]{2}{*}{ Nature of Occurrence } & \multicolumn{2}{|c|}{ External Injury to Abdomen } \\
\hline & $\begin{array}{c}\text { Present } \\
\text { N (\%) }\end{array}$ & $\begin{array}{l}\text { Absent } \\
\text { N (\%) }\end{array}$ \\
\hline $\begin{array}{c}\text { Road traffic } \\
\text { (pedestrian) }(n=16)\end{array}$ & $9(56.3)$ & $7(43.7)$ \\
\hline $\begin{array}{c}\text { Road traffic } \\
\text { (occupant) }(\mathrm{n}=43)\end{array}$ & $19(44.2)$ & $24(55.8)$ \\
\hline $\begin{array}{c}\text { Railway occurrence } \\
(\mathrm{n}=11)\end{array}$ & $8(72.7)$ & $3(27.3)$ \\
\hline Fall from height $(n=7)$ & $4(57.1)$ & $3(42.9)$ \\
\hline $\begin{array}{l}\text { Fall of objects on body } \\
(n=3)\end{array}$ & $0(0)$ & $3(100)$ \\
\hline $\begin{array}{l}\text { Injury with weapons } \\
(\mathrm{n}=3)\end{array}$ & $2(66.6)$ & $1(33.4)$ \\
\hline Injury by animals $(\mathrm{n}=1)$ & $1(100)$ & $0(0)$ \\
\hline Others $(n=4)$ & $1(25)$ & $3(75)$ \\
\hline Total (N=88) (100) & $44(50)$ & $44(50)$ \\
\hline \multicolumn{3}{|c|}{$\begin{array}{l}\text { Table 2. Occurrence of in Traumatic Liver Injury with } \\
\text { and Without External Injury }(N=88)\end{array}$} \\
\hline
\end{tabular}




\begin{tabular}{|c|c|c|c|}
\hline Nature of Occurrence & Abrasion & Contusion & Laceration \\
\hline Road traffic (pedestrian) $(\mathrm{n}=16)$ & $4(25.0)$ & $5(31.3)$ & $2(12.5)$ \\
\hline Road traffic (occupant) (n=43) & $15(34.9)$ & $4(9.3)$ & $2(4.6)$ \\
\hline Railway occurrence (n=11) & $5(45.5)$ & $2(18.2)$ & $5(45.5)$ \\
\hline Fall from height $(n=7)$ & $3(42.9)$ & $1(14.3)$ & $0(0)$ \\
\hline Fall of objects on body $(n=3)$ & $0(0)$ & $0(0)$ & $0(0)$ \\
\hline Injury with weapons (n=3) & $0(0)$ & $1(33.3)$ & $0(0)$ \\
\hline Injury by animals (n=1) & $0(0)$ & $1(100)$ & $0(0)$ \\
\hline Others $(n=4)$ & $1(25)$ & $0(0)$ & $0(0)$ \\
\hline Total $(\mathrm{N}=88)$ & $28(31.8)$ & $14(15.9)$ & $9(10.2)$ \\
\hline
\end{tabular}

\begin{tabular}{|c|c|}
\hline Nature of Occurrence & $\begin{array}{c}\text { No: of Cases without External Injury to Abdomen but with External Injury to } \\
\text { Chest }\end{array}$ \\
\hline Road traffic (pedestrian) $(\mathrm{n}=16)$ & $15(93.7)$ \\
\hline Road traffic (occupant) (n=43) & $4(9.3)$ \\
\hline Railway occurrence (n=11) & $2(18.2)$ \\
\hline Fall from height $(\mathrm{n}=7)$ & $3(42.8)$ \\
\hline Fall of objects on body $(n=3)$ & $3(100)$ \\
\hline Injury with weapons $(\mathrm{n}=3)$ & $1(33.3)$ \\
\hline Injury by animals $(\mathrm{n}=1)$ & $0(0)$ \\
\hline Others $(n=4)$ & $1(25)$ \\
\hline Total $(\mathrm{N}=88)$ & $29(32.9)$ \\
\hline
\end{tabular}

\begin{tabular}{|c|c|c|c|c|c|c|}
\hline $\begin{array}{c}\text { Nature of Occurrence } \\
\text { Category in Traumatic } \\
\text { Liver Injury }\end{array}$ & $\begin{array}{l}\text { Head } \\
\text { Injury } \\
\mathrm{N}(\%) \\
\end{array}$ & $\begin{array}{l}\text { Chest } \\
\text { Injury } \\
\text { N (\%) } \\
\end{array}$ & $\begin{array}{c}\text { Other Abdominal } \\
\text { Organ Injury } \\
\text { N (\%) }\end{array}$ & $\begin{array}{c}\text { Long Bone } \\
\text { Fracture } \\
\mathrm{N}(\%) \\
\end{array}$ & $\begin{array}{c}\text { Right-Sided } \\
\text { Rib Fracture } \\
\text { N (\%) } \\
\end{array}$ & $\begin{array}{c}\text { Multiple } \\
\text { Injuries } \\
\text { N (\%) }\end{array}$ \\
\hline $\begin{array}{l}\text { Road traffic (pedestrian) } \\
(\mathrm{n}=16)\end{array}$ & $8(50)$ & $\begin{array}{c}15 \\
(93.7) \\
\end{array}$ & 7 (43.7) & $5(31.2)$ & $12(0.75)$ & $12(0.75)$ \\
\hline $\begin{array}{l}\text { Road traffic (occupant) } \\
(\mathrm{n}=43)\end{array}$ & $\begin{array}{c}35 \\
(81.4)\end{array}$ & $\begin{array}{c}27 \\
(62.8)\end{array}$ & $9(20.9)$ & 8 (18.6) & $22(51.2)$ & $27(62.8)$ \\
\hline $\begin{array}{c}\text { Railway occurrence } \\
(\mathrm{n}=11)\end{array}$ & 9 (81.9) & 9 (81.9) & $6(54.5)$ & $3(27.2)$ & 9 (81.9) & 9 (81.9) \\
\hline $\begin{array}{c}\text { Fall from height } \\
(\mathrm{n}=7)\end{array}$ & $3(42.8)$ & 5 (71.4) & 4 (57.1) & $1(14.2)$ & $4(57.1)$ & $4(57.1)$ \\
\hline $\begin{array}{l}\text { Fall of objects on body } \\
(\mathrm{n}=3)\end{array}$ & $3(100)$ & $2(66.6)$ & $2(66.6)$ & $0(0)$ & $1(33.3)$ & $3(100)$ \\
\hline $\begin{array}{c}\text { Injury with weapons } \\
(\mathrm{n}=3)\end{array}$ & $0(0)$ & $2(66.6)$ & $1(33.3)$ & $1(33.3)$ & $1(33.3)$ & $1(33.3)$ \\
\hline $\begin{array}{c}\text { Injury by animals } \\
(\mathrm{n}=1)\end{array}$ & $0(0)$ & $1(100)$ & $1(100)$ & $0(0)$ & $1(100)$ & $1(100)$ \\
\hline $\begin{array}{c}\text { Others } \\
(\mathrm{n}=4)\end{array}$ & $0(0)$ & $2(50)$ & $1(25)$ & $0(0)$ & $1(25)$ & $1(25)$ \\
\hline Total $(\mathrm{N}=88)$ & $\begin{array}{c}58 \\
(65.9)\end{array}$ & $\begin{array}{c}63 \\
(71.6)\end{array}$ & $31(35.2)$ & $18(20.4)$ & $51(57.9)$ & 58 (65.9) \\
\hline
\end{tabular}

\begin{tabular}{|c|c|}
\hline $\begin{array}{c}\text { Period of Survival } \\
\text { (In Hours) }\end{array}$ & $\begin{array}{c}\text { No: of Cases } \\
\text { N (\%) }\end{array}$ \\
\hline$<0$ (Death at site) & $29(32.9)$ \\
\hline$>0-1$ & $33(37.5)$ \\
\hline $1-12$ & $16(18.2)$ \\
\hline $12-24$ & $4(4.5)$ \\
\hline$>24$ & $6(6.8)$ \\
\hline Total & $\mathbf{8 8}(\mathbf{1 0 0})$ \\
\hline Table 6. Period of Survival in Traumatic Liver Injury Victims. $(\mathbf{N = 8 8 )}$ \\
\hline
\end{tabular}



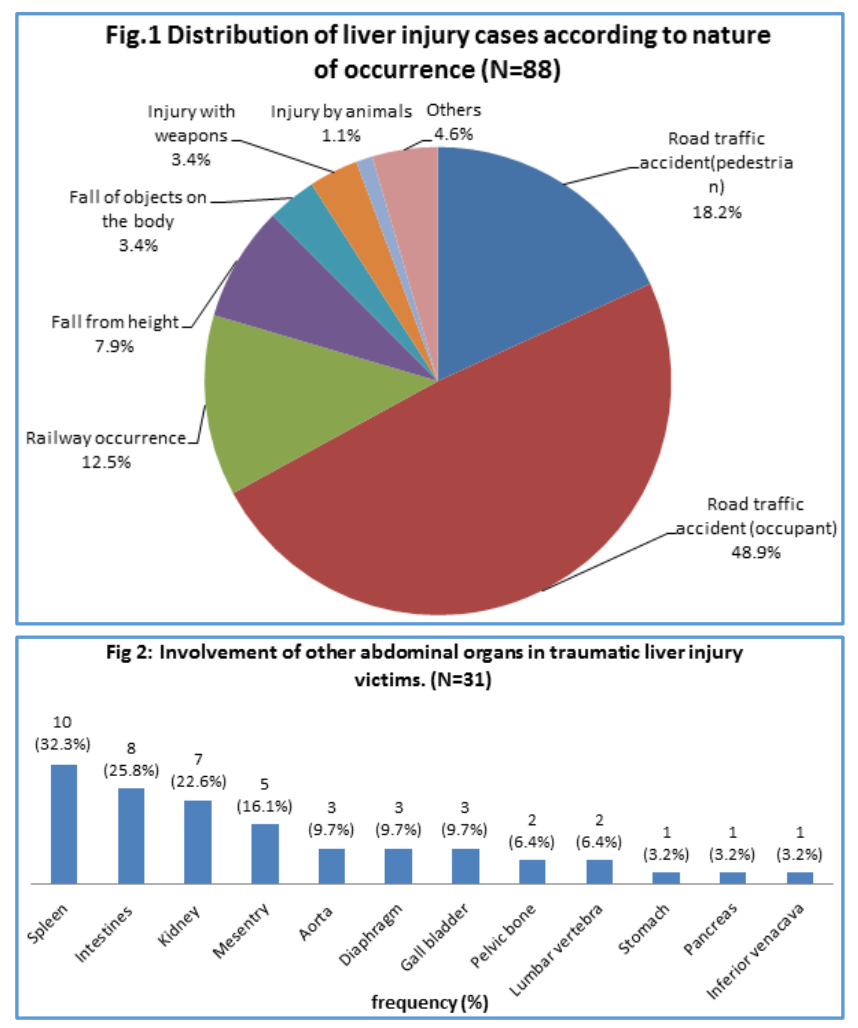

\section{DISCUSSION}

Non-penetrating liver injuries were the major type of traumatic liver injuries as observed in $97.7 \%$ of cases. ${ }^{5}$ Road traffic accidents $(67 \%)$ were the most common cause of occurrence in the present study, and similar findings were observed in other studies.6,7 Railway occurrences were responsible for $12.5 \%$, and $7.95 \%$ were due to fall from heights. In traffic accidents, $48.86 \%$ were occupants of various types of vehicles and $18.18 \%$ were pedestrians.

The study shows that in traumatic liver injury cases, commonly associated with blunt trauma, the chance of mortality is high considering the fact that even among those patients who received treatment $(23.9 \%)$, in majority of the cases, 18 (85.71\%), liver injury was not suspected or detected clinically. ${ }^{8}$ Thirty three victims (37.5\%) died within an hour. Concealed haemorrhage is the second most common cause of death after trauma, and missed abdominal injuries are a frequent cause of morbidity and late mortality in patients who survive the early period after injury. ${ }^{9}$

Only in $50 \%$ cases of liver injury there was external injury to the abdomen. A similar study done in India also shows that in liver injury patients, only $50 \%$ of the cases had external injury in abdomen. ${ }^{8}$ Associated fatal injuries were found in the chest in $71.6 \%$ cases. Right-sided rib fractures were found in $57.9 \%$ cases. Fractured ends of ribs were responsible for most of the lung lacerations and associated injury to right lobe of liver. A few other studies also showed increased involvement of right lobe and anterior surface. ${ }^{6}$ Fatal brain injury was seen in $65.9 \%$ of cases. Associated fatal injury to other abdominal organ was observed in 31 cases (35.22\%). Spleen was the organ frequently affected (32.3\%). ${ }^{10}$ Fracture of vertebral column was observed in $14(15.9 \%)$ cases.

\section{CONCLUSIONS}

The most common cause of liver injury was road traffic accidents followed by railway occurrences. Among abdominal viscera, spleen was the most commonly injured organ along with liver followed by intestine. Liver can be injured without any injury to the abdominal wall as seen in $50 \%$ cases. The role of liver injury contributing to death when associated with injuries to other vital organs could not be discerned in all cases. Incidence of right-sided rib fracture was an associated feature in $57.9 \%$ cases. Chest injury was frequently observed along with liver injury (71.6\%). Pattern of external injury has no definite relationship with the liver injury. The site of external injury appears to be more important.

\section{Acknowledgements}

We would like to express our heartfelt thanks to the teachers (Dr. Sreekumari. K and Dr. Kurian Kuriakose) and staff of Department of Forensic Medicine, Thiruvananthapuram for their invaluable contributions in this study.

\section{REFERENCES}

1. Decker GA. Lee McGregor's synopsis of surgical anatomy. Bristol: John Wright and Sons Ltd., 1986.

2. Viano DC, King AI. Biomechanics of chest and abdomen impact. In: Bronzino JD. edr. The biomedical engineering handbook. 2nd edn. Boca Raton: CRC Press LLC 2000.

3. Zangana AM. Penetrating liver war injury: a report on 676 cases, after Baghdad invasion and Iraqi civilian war April 2003. J of Advances in Medical and Dental Sciences 2007;1(1):10-14.

4. Khan NA, Vadeyar H, MacDonald S, et al. Liver Trauma. 2009. www.emedicine.com/radio/topic397.htm

5. Subedi N, Yadav BN, Jha S, et al. An autopsy study of liver injuries in a tertiary referral centre of eastern Nepal. J Clin Diagn Res 2013;7(8):1686-8.

6. Chakraborty P, Das S, Pandey SK. Comparative study of hepatic injury and its different aspects in medicolegal autopsies. J Indian Acad Forensic Med 2011;33(3):203-5.

7. Alison. Surgical restraint in the management of liver trauma. Br J Surgery 1991;78(9):1071-5.

8. Punia RK, Meena DS, et al. Missed injuries in fatal blunt thoraco - abdominal region. J Indian Acad Forensic Med 2013;35(3):230-32.

9. Gilroy D. Deaths from blunt trauma, after arrival at hospital: plus ça change, plus c'est la même chose. Injury 2005;36(1):47-50.

10. Zargar M, Laal M. Liver trauma: operative and nonoperative management. International Journal of Collaborative Research on Internal Medicine \& Public Health 2010;2(4):96-107. 